AGRICULTURE AND BIOLOGY JOURNAL OF NORTH AMERICA

ISSN Print: 2151-7517, ISSN Online: 2151-7525, doi:10.5251/abjna.2010.1.5.1001.1008

(C) 2010, ScienceHuß, http://www.scihub.org/ABJNA

\title{
Insecticidal activities of neem (Azadirachta indica A. Juss) seeds under laboratory and field conditions as affected by different storage durations
}

\author{
Abdalla Abdelrahim Satti, Mohamed Elamin Ellaithy and Abdin Elhadi Mohamed
}

\author{
Environment and Natural Resources Research Institute (ENRRI), National Centre for \\ Research (NCR), Khartoum, Sudan, \\ Corresponding author: Abdalla Abdelrahim Satti, phone number 00249916017797 , \\ E-mail: satisattisat@yahoo.com
}

\begin{abstract}
Neem seed water extract is found to be very potent in combating various pests of storage and field crops in Sudan, and recommended for use in small holding farms. Two laboratory tests on Trogodarma granariun and a field experiment on okra crop were carried out to compare the insecticidal activities of several water extracts prepared from neem seeds stored at different durations (1-5 years) under room conditions. Such field study also compared extracts of corticated with decorticated seeds. The laboratory tests showed that neem seeds stored at 2, 3 and 4 years were better than the seeds stored at 1 or 5 years, in controlling the studied pest. The newest seeds (1year) seemed to exert more repellent effect than older seeds, while diminishing of neem activities appeared to start after four years of storage when applied under shade. On the other hand, field results reflected that all evaluated neem seeds of three storage periods (ca. 1, 2 and 3 years) significantly suppressed pests' populations, increased marketable yields and saved the prevailing predators. They all, except the oldest seeds (3 years), showed comparable or even better performance than the commercial insecticide used. Thus, declining of seeds activities under field situation was recorded with seeds of three years old. However, field results also proved the superiority of corticated neem seeds over that of decorticated. It is concluded that, neem seeds stored in jute sacks under shade, can remain as potent as new seeds for up to four and two years, regarding their uses for pests control either in storage or field crops, respectively. Corticated neem seeds were recommended for pests control instead of decorticated ones.
\end{abstract}

Keywords: Neem, storage durations, Trogoderma granarium, okra insects.

\section{INTRODUCTION}

Extensive usage of broad spectrum synthetic pesticides during the last century has created so many environmental problems worldwide, and particularly in Sudan (Liedholm and Amisi, 1986, and Abdel Bagi et al., 2006). Moreover, pest resistance to pesticides and consequently the increased costs of production have also aggravated the drawbacks of these chemicals (Abdel Daffie et al., 1987, and Assad et al., 2006). Therefore, various alternative measures of pests control were studied during the last decades, including botanical extracts (Whitehead and Bowers, 1983, and Satti et al., 2004)). Among the recognized pesticidal plants, the neem tree, Azadirachta indica A. Juss, proved its unique source for numerous active ingredients of insecticidal properties. This tree has attracted the special interest in the field of plant protection and agro-industry, and some commercial neem insecticides were formulated (Schmutterer, 1990).

Seed kernel represents the most important source of active ingredients found in neem tree, such as azadirachtin and many others. Neem ingredients affect insects in various ways including mainly repellent, antifeedant, toxic and growth regulatory effects. Fecundity of insects was also affected by various neem products. However, neem-based products were proved as medium- to broad-spectrum insecticides against various field and store pests (Schmutterer, 1990). Furthermore, the latter author concluded that neem products are suitable for integrated pest management because of their low toxicity to non target organisms, easy preparation and compatibility with other bio-products. In Sudan, several products (i.e., powder, and water and organic extracts) of neem seeds showed significant control of insect pests on post harvests as well as on some 
vegetable crops under field conditions. The results were generally comparable or sometimes better than the commercial insecticides used (Siddig, 1991; Ahmed, 1997, and Satti et al., 2003). The optimum dosage rates of water extracts were indicated and recommended for important vegetables, so that they can be prepared and applied by subsistence farmers wherever needed (Siddig, 1987; Mohamed, 2002, and Satti and Nasr, 2006a,b).

Therefore, farmers and even researchers generally collect their neem stock during the limited fruiting period every year from June to July. This is because neem berries left under trees after this period in most locations, will get spoiled through the rain water during autumn (August - October). On the other hand, another problem facing neem users is that they have to decorticate the seeds before preparing the seed kernel extracts, a task which is extremely difficult due to unavailability of seed decorticators. However, seed cortex is generally crushed manually using stones or pestles, and then winnowed so as to obtain clean kernels. Since neem fruits stored at different years were observed to be used for pests control by following the previous procedures, hence, the aim of this research was to clarify the following points; a) to evaluate the insecticidal activities of water extracts prepared from neem seeds stored at different durations ( $1-5$ years) against some pests of store products (viz., Trogoderma granarium) and field crops (okra insects), and b) to test and compare extracts from corticated and decorticated seeds under the field experiment.

\section{MATERIALS AND METHODS}

Laboratory Tests: Two laboratory experiments were conducted at the Environment and Natural Resources Research Institute (ENRRI), National Centre for Research (NCR), Khartoum-Sudan, to compare the insecticidal effects of neem seeds water extracts prepared from neem fruits stored at different durations. Neem berries, products of the years 2003 to 2008 were already collected from Shambat area, Khartoum North, and stored in jute sacks under room conditions, to be used for the research purposes. The first experiment was conducted in 2005 utilizing water extracts of neem products stored at one (product of 2004) and two (2003) years, followed by the second experiment in 2009 compared seeds water extracts from neem products of five years $(2004-2008)$.

Preparations of neem extracts: The steps of neem extract preparation adopted by Siddig (1991) were applied with slight modifications. Neem fruits indicated for each experiment were soaked in water for 24 hrs to facilitate the removal of seeds. Dried seeds were decorticated and crushed into fine powders using an electric blender (Moulinex). The required powder weights were dissolved in water, stirred on a magnetic stirrer and allowed to stand overnight before filtration. Five concentrations (12\%, $6 \%, 3 \%, 1.5 \%$ and $0.75 \%$; w/v) from each extract were applied in the $1^{\text {st }}$ experiment, and three concentrations $(5 \%, 2.5 \%$ and $1.25 \% ; w / v)$ in the $2^{\text {rd }}$ experiment.

Bioassay tests: According to the number of treatments shown above for each experiment, the required Petri dishes replicated three times were prepared. Each Petri dish was occupied with five grams of sound and clean sorghum seeds treated with the respective extract concentration. The $3^{\text {rd }}$ instar larvae of the khapra beetle (Trogoderma granarium) were used in the bioassay, as test insect. Five larvae were introduced in each Petri dish with the seeds and covered. All experiments were assigned in a Completely Randomized Design (CRD). Counts on larval mortalities and observational records on larval behaviour or any morphological disorders were done at regular intervals from treatments. The seeds were weighed again at the end of the first experiment to compare the loss in seeds weights among different treatments. Data were tabulated and analyzed statistically according to the CRD ANOVA. Whenever significant differences were detected, means separation was followed applying Duncan's Multiple Range test.

Field Experiment: The field experiment was conducted on okra crop (cv. Pusa Sawani) during winter season from Jan. to March 2006, at El-Shaab Agricultural scheme in northern Khartoum. The treatments were assigned in a Randomized Complete Block design to fulfill the following objectives:

- To study the insecticidal activities of water extracts prepared from neem seeds stored at three different durations (ca. 1-3 years) against insect pests and predators of okra crop and its yield under field situation.

- To compare between corticated and decorticated neem seed extracts, regarding their insecticidal efficacies and extract yields.

Treatments: Six treatments were executed for the field study included; three water extracts prepared from corticated neem seeds of three years (2003, 2004 and 2005) and one water extract from 
decorticated seeds of the last year (2005), in addition to a commercial insecticide Valerate 20\%EC (fenvalerate) and an untreated control for comparison. Preparation of neem extracts followed the same procedures mentioned for laboratory tests, but decortication a step was only made for one treatment as mentioned above. Such decorticated seed extract was applied at the rate of $4 \% \mathrm{w} / \mathrm{v}(40 \mathrm{~g}$ seed kernel powder/ 1L. water) as recommended (Mohamed, 2002). Because seed cortex represents about $54 \%$ of the seed weight (Satti et al., 2002), i.e., nearly equal of seed kernel weight, the three treatments of corticated seeds were sprayed at the rate of $8 \% \mathrm{w} / \mathrm{v}$ ( $80 \mathrm{~g}$ corticated seed powder/ $1 \mathrm{~L}$. water).

Spraying and data collection: Count of insect pests and predators was started about one month from crop sowing, and continued regularly as pre- and post-spray counts. The total population number of each species was counted per fifty leaves of ten randomly selected plants per plot. Four sprays were conducted for neem treatments and the insecticide, at 15 days intervals. An average of six pickings of okra pods were taken to compare between yields of different treatments. All data were analyzed following the indicated design, and means separation was applied whenever needed using Duncan's Multiple Range test.

\section{RESULTS AND DISCUSSION}

Laboratory Results: The results of the first experiment are shown in Table 1. During the first 10 days interval, three concentrations $(12 \%, 6 \%$ and $3 \%$ ) of the oldest neem seeds (2003) induced significantly higher insect mortalities than the control, while in the freshly one-year old seeds (2004) only the highest $12 \%$ concentration was significantly the best. Thenceforth, during the rest period of the experiment, the mortality effects of all extract concentrations from the former seeds (2003) were superior to those obtained from the new seeds. The mortality rates were mainly increased with time and concentration. New seeds were observed to exert strong repellent action and antifeedant effect on the pest, as the larvae were found crawling away from treated sorghum grains in Petri dishes with minimal feedings. Therefore, few percentages of grains were consumed by the larvae in these treatments (2.6 $5.2 \%$; Table1) as compared with treatments of the year $2003(4.6-6.6 \%)$. Nevertheless, no significant differences were detected between concentrations of both neem extracts, and all treatments significantly reduced grains damage compared with controls. In other way, it can be said that the repellent and antifeedant effects of stored neem were reduced soon within one year of storage, although its toxic effect was maintained for relatively longer time. This assumed to be more logical than the other interpretation which referred the inferiority of fresh seed mortality to the fact that fresh neem seed may requires some period probably extending for one year or more so as to gain its full concentration and toxic activities. Moreover, it was also observed that none died larvae on the lowest concentrations of the new seed extract showed extended life periods as larval stage compared to the control at the end of the experiment, a phenomenon which may suggests the occurrence of neem hormonal effect on insect. In contrast, all larvae on treatments of oldest seeds were eventually died and those on controls were developed into adults, within relatively short periods.

Table 1. Effects of neem seeds water extracts of two years (2003 and 2004) on mortalities and feedings of the $3^{\text {rd }}$ instar larvae of Trogoderma granarium, at different intervals from treatments, during August 2005.

\begin{tabular}{|c|c|c|c|c|c|}
\hline \multirow[t]{2}{*}{ Treatments } & \multicolumn{3}{|c|}{ 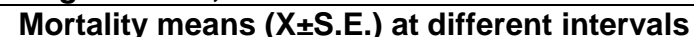 } & \multicolumn{2}{|c|}{ Seeds consumed } \\
\hline & 10 days & 21 days & 30 days & X土S.E. & $\%$ \\
\hline NSK.WE-2003, at $12 \%$ & $2.3 \pm 1.1 b$ & $4.3 \pm 0.3 \mathrm{ab}$ & $5.0 \pm 0.0 \mathrm{a}$ & $0.2 \pm 0.1 \mathrm{~cd}$ & $4.6 \%$ \\
\hline NSK.WE-2003, at 6\% & $3.3 \pm 0.7 b$ & $4.3 \pm 0.7 \mathrm{ab}$ & $4.7 \pm 0.3 \mathrm{a}$ & $0.3 \pm 0.1 \mathrm{bcd}$ & $5.2 \%$ \\
\hline NSK.WE-2003, at 3\% & $2.7 \pm 0.5 b$ & $4.3 \pm 0.7 \mathrm{ab}$ & $4.7 \pm 0.3 a$ & $0.3 \pm 0.1 \mathrm{bcd}$ & $6.0 \%$ \\
\hline NSK.WE-2003, at $1.5 \%$ & $1.7 \pm 0.3 \mathrm{bc}$ & $4.3 \pm 0.3 \mathrm{ab}$ & $4.7 \pm 0.3 \mathrm{a}$ & $0.3 \pm 0.0 \mathrm{bcd}$ & $6.0 \%$ \\
\hline NSK.WE-2003, at $0.75 \%$ & $1.3 \pm 0.7 b c$ & $4.0 \pm 0.6 \mathrm{ab}$ & $4.7 \pm 0.3 a$ & $0.3 \pm 0.0 \mathrm{bcd}$ & $6.6 \%$ \\
\hline NSK.WE-2004, at 12\% & $3.7 \pm 0.7 \mathrm{a}$ & $5.0 \pm 0.0 \mathrm{a}$ & $5.0 \pm 0.0 \mathrm{a}$ & $0.1 \pm 0.0 \mathrm{~d}$ & $2.6 \%$ \\
\hline NSK.WE-2004, at $6 \%$ & $1.3 \pm 0.3 b c$ & $3.7 \pm 0.3 b c$ & $4.3 \pm 0.3 \mathrm{a}$ & $0.2 \pm 0.0 \mathrm{~cd}$ & $3.2 \%$ \\
\hline NSK.WE-2004, at 3\% & $1.7 \pm 0.3 a b c$ & $3.3 \pm 0.3 \mathrm{bcd}$ & $4.3 \pm 0.3 a$ & $0.2 \pm 0.0 \mathrm{~cd}$ & $4.6 \%$ \\
\hline NSK.WE-2004, at $1.5 \%$ & $0.3 \pm 0.3 \mathrm{c}$ & $2.0 \pm 0.6 \mathrm{de}$ & $2.3 \pm 0.3 b c$ & $0.2 \pm 0.0 \mathrm{~cd}$ & $4.6 \%$ \\
\hline NSK.WE-2004, at $0.75 \%$ & $1.3 \pm 0.3 b c$ & $2.3 \pm 0.9 \mathrm{~cd}$ & $2.7 \pm 0.9 b$ & $0.3 \pm 0.0 \mathrm{bcd}$ & $5.2 \%$ \\
\hline Control (untreated) & $0.0 \pm 0.0 \mathrm{c}$ & $0.0 \pm 0.0 \mathrm{e}$ & $0.0 \pm 0.0 \mathrm{c}$ & $0.5 \pm 0.0 \mathrm{a}$ & $9.2 \%$ \\
\hline C.V.\% & 0.6 & 0.3 & 0.2 & 8.2 & \\
\hline
\end{tabular}

$>$ NSK.WE $=$ Neem seed kernels water extract.

$>$ Means with the same letter (s), in each column, are not significantly different (at $p=0.05)$ according to Duncan's Multiples Range test. 
Several authors confirmed the presence of numerous active ingredients in neem (Schmutterer, 1990, 1995, and Bashir, 1994). Such active ingredients are responsible for several biological activities in insects, including repellent, antifeedant, toxic and hormonal effects (Dreyer, 1984; Ketkar, 1987; Saxena et al., 1989; Zein Elabdin and Siragelnour, 1993; Gorashi et al., 1994; Saxena 1995, and Schmutterer, 1990, 1995). According to the latter author the toxic effect of neem ingredients generally acts through stomach action rather than contact action. This interpreted why neem products exerted delayed mortality effects on insects which increased with time and concentration as explained in the present results, and other previous works (Satti et al., 2003, Satti and Nasr, 2006a,b).

Data comparing water extracts of neem seeds stored at five different durations (i.e., 1 - 5 years) were explained in Table 2. The results were more or less confirmed what have been obtained in the first experiment. Accordingly, mortality trends increased gradually with time, where significant effects were found by most treatments during last intervals (after 10 days). Extracts of neem seeds stored at 2 to 4 years exerted higher mortality rates on the pest than extracts of the newest ( 1 year old) and the oldest ( 5 years old) seeds. To our knowledge, no similar studies have addressed neem insecticidal effects as affected by storage durations. But, as raised before, the strong repellent and/or antifeedant effects of fresh neem could be one of the main reasons which make insects to avoid feedings, and hence reduced or delayed mortalities compared with the other treatments. On the other hand, diminishing of neem seed insecticidal action was started after four years of storage under shade conditions. Whatever the case, such period of seed activity may be shortened or even lengthened depending on the prevailing storage conditions. Effects of environmental factors on neem active substances were reported by Schmutterer (1988, 1990, 1995), who emphasized the importance of keeping these products away from such conditions like UV light, rainfall and high temperatures to minimize degradation.

Table 2. Effects of different water extracts from neem seeds stored at one to five years (2004 - 2008$)$ on mortalities of the $3^{\text {rd }}$ instar larvae of Trogoderma granarium, at different intervals from treatments, during August 2009.

\begin{tabular}{|l|l|l|l|l|l|}
\hline \multirow{2}{*}{ Treatments } & \multicolumn{5}{|c|}{ Mortality means (X+S.E.) at different intervals } \\
\cline { 2 - 6 } & 2 days & $\mathbf{5}$ days & $\mathbf{1 0}$ days & 15 days & 21 days \\
\hline NSK.WE-2004, 5\% & $0.0 \pm 0.0 \mathrm{a}$ & $0.8 \pm 0.5 \mathrm{ab}$ & $1.0 \pm 0.4 \mathrm{bcd}$ & $3.0 \pm 0.4 \mathrm{cde}$ & $5.3 \pm 0.8 \mathrm{bcd}$ \\
NSK.WE-2004, 2.5\% & $0.3 \pm 0.3 \mathrm{a}$ & $1.0 \pm 0.6 \mathrm{ab}$ & $1.0 \pm 0.6 \mathrm{bcd}$ & $2.3 \pm 0.8 \mathrm{de}$ & $5.3 \pm 0.8 \mathrm{bcd}$ \\
NSK.WE-2004,1.25\% & $0.0 \pm 0.0 \mathrm{a}$ & $0.8 \pm 0.5 \mathrm{ab}$ & $1.0 \pm 0.4 \mathrm{bcd}$ & $2.3 \pm 0.6 \mathrm{de}$ & $4.5 \pm 0.5 \mathrm{~cd}$ \\
NSK.WE-2005, 5\% & $0.0 \pm 0.0 \mathrm{a}$ & $1.3 \pm 0.5 \mathrm{ab}$ & $1.5 \pm 0.7 \mathrm{abcd}$ & $4.8 \pm 0.3 \mathrm{abc}$ & $6.3 \pm 0.8 \mathrm{abc}$ \\
NSK.WE-2005, 2.5\% & $0.0 \pm 0.0 \mathrm{a}$ & $0.5 \pm 0.5 \mathrm{ab}$ & $2.0 \pm 0.6 \mathrm{ab}$ & $4.8 \pm 0.8 \mathrm{abc}$ & $6.3 \pm 0.8 \mathrm{abc}$ \\
NSK.WE-2005,1.25\% & $0.3 \pm 0.3 \mathrm{a}$ & $1.5 \pm 0.7 \mathrm{a}$ & $2.3 \pm 0.9 \mathrm{ab}$ & $4.3 \pm 0.8 \mathrm{bcde}$ & $6.5 \pm 0.9 \mathrm{ab}$ \\
NSK.WE-2006, 5\% & $0.0 \pm 0.0 \mathrm{a}$ & $1.8 \pm 0.5 \mathrm{a}$ & $2.8 \pm 0.5 \mathrm{a}$ & $5.8 \pm 0.3 \mathrm{ab}$ & $7.3 \pm 0.3 \mathrm{a}$ \\
NSK.WE-2006, 2.5\% & $0.0 \pm 0.0 \mathrm{a}$ & $0.5 \pm 0.3 \mathrm{ab}$ & $1.0 \pm 0.4 \mathrm{bcd}$ & $4.0 \pm 0.7 \mathrm{bcde}$ & $5.0 \pm 0.7 \mathrm{bcd}$ \\
NSK.WE-2006,1.25\% & $0.3 \pm 0.3 \mathrm{a}$ & $1.0 \pm 0.0 \mathrm{ab}$ & $1.8 \pm 0.5 \mathrm{abc}$ & $3.8 \pm 0.3 \mathrm{cde}$ & $5.8 \pm 0.3 \mathrm{abcd}$ \\
NSK.WE-2007, 5\% & $0.3 \pm 0.3 \mathrm{a}$ & $1.0 \pm 0.4 \mathrm{ab}$ & $1.8 \pm 0.5 \mathrm{abc}$ & $6.0 \pm 0.7 \mathrm{a}$ & $6.8 \pm 0.5 \mathrm{ab}$ \\
NSK.WE-2007, 2.5\% & $0.0 \pm 0.0 \mathrm{a}$ & $0.5 \pm 0.3 \mathrm{ab}$ & $0.8 \pm 0.2 \mathrm{bcd}$ & $4.5 \pm 0.3 \mathrm{abcd}$ & $6.0 \pm 0.4 \mathrm{abcd}$ \\
NSK.WE-2007,1.25\% & $0.0 \pm 0.0 \mathrm{a}$ & $0.5 \pm 0.3 \mathrm{ab}$ & $1.0 \pm 0.4 \mathrm{bcd}$ & $4.0 \pm 0.7 \mathrm{bcde}$ & $5.3 \pm 0.5 \mathrm{bcd}$ \\
NSK.WE-2008, 5\% & $0.0 \pm 0.0 \mathrm{a}$ & $0.5 \pm 0.3 \mathrm{ab}$ & $1.3 \pm 0.6 \mathrm{abc}$ & $4.0 \pm 0.4 \mathrm{bcde}$ & $5.0 \pm 0.6 \mathrm{bcd}$ \\
NSK.WE-2008, 2.5\% & $0.0 \pm 0.0 \mathrm{a}$ & $0.8 \pm 0.3 \mathrm{ab}$ & $2.3 \pm 0.3 \mathrm{ab}$ & $4.3 \pm 0.3 \mathrm{bcdl}$ & $5.3 \pm 0.3 \mathrm{bcd}$ \\
NSK.WE-2008,1.25\% & $0.0 \pm 0.0 \mathrm{a}$ & $0.0 \pm 0.0 \mathrm{~b}$ & $0.3 \pm 0.3 \mathrm{~cd}$ & $2.5 \pm 0.3 \mathrm{e}$ & $4.3 \pm 0.3 \mathrm{~d}$ \\
Control (untreated) & $0.0 \pm 0.0 \mathrm{a}$ & $0.0 \pm 0.0 \mathrm{~b}$ & $0.0 \pm 0.0 \mathrm{~d}$ & $0.0 \pm 0.0 \mathrm{f}$ & $0.0 \pm 0.0 \mathrm{e}$ \\
\hline C.V.\% & 400.0 & 102.8 & 72.1 & 28.3 & 20.4 \\
\hline
\end{tabular}

$>$ NSK.WE $=$ Neem seed kernels water extract.

$>$ Means with the same letter (s), in each column, are not significantly different (at $p=0.05)$ according to Duncan's Multiples Range test.

Field Results: Table 3 showed the count results of foliage pests and predators of okra crop under field conditions. The recorded insect pests in this experiment were; the cotton aphid (Aphis gossypii), cotton whitefly (Bemisia tabaci), cotton jassid (Jacobiasca lybica), leaf miners (Liriomyza spp.) and the spotted bollworm (Earias vittella), while the

common predators included; Chrysoperla carnea, Schymnus spp., Hippodamia variegata, Xanthogramma spp. and different spiders. All neem treatments almost manifested significant effects in controlling all pests, during the different counting intervals. Some research works in Sudan also explained similar results (Satti and Nasr, 2006a,b). 
Considering the corticated seeds, no significant differences were found between the studied extracts of the three years (2003-2005) in aphid control, but extract of the oldest seeds (2003) generally sustained the highest population. These results also more or less applied to other pests especially jassid and leaf miners, but the whitefly recorded insignificantly little occurrence during the season. Such field results were contrasted laboratory tests in two points: Firstly,

Table 3. Field evaluation of corticated neem seeds water extracts, from products of three storage periods (2003 2005), and a decorticated seed extract of the year 2005, against okra pests and predators, during Jan. March 2006.

\begin{tabular}{|c|c|c|c|c|}
\hline \multirow[t]{2}{*}{ Insect species/ Treatments } & \multicolumn{4}{|c|}{ Insect mean counts/ 50 leaves } \\
\hline & Initial & Post-spray & Pre-spray & G.P. \\
\hline $\begin{array}{l}\text { Aphids: } \\
\text { NS-WE, 8\%w/v, } 2003 \\
\text { NS-WE, 8\%w/v, } 2004 \\
\text { NS-WE, 8\%w/v, } 2005 \\
\text { NSK-WE, 4\%w/v, } 2005 \\
\text { Valerate 20\%EC, (0.7L/ha) } \\
\text { Control (untreated) }\end{array}$ & $\begin{array}{l}222.33 \\
234.00 \\
367.00 \\
215.67 \\
265.67 \\
197.67\end{array}$ & $\begin{array}{r}329.92 b \\
206.42 b \\
171.92 b \\
542.89 b \\
1651.42 a \\
1795.25 a\end{array}$ & $\begin{array}{r}304.67 \mathrm{c} \\
221.22 \mathrm{c} \\
249.44 \mathrm{c} \\
737.33 \mathrm{c} \\
6552.22 \mathrm{a} \\
2025.61 \mathrm{~b} \\
\end{array}$ & $\begin{array}{r}319.09 b \\
212.76 b \\
205.14 b \\
640.11 b \\
3751.76 a \\
2529.43 a\end{array}$ \\
\hline C.V.\% & & 51.52 & 71.24 & 61.89 \\
\hline $\begin{array}{l}\text { Whiteflies: } \\
\text { NS-WE, 8\%w/v, } 2003 \\
\text { NS-WE, 8\%w/v, } 2004 \\
\text { NS-WE, 8\%w/v, } 2005 \\
\text { NSK-WE, 4\%w/v, 2005 } \\
\text { Valerate 20\%EC, (0.7L/ha) } \\
\text { Control (untreated) }\end{array}$ & $\begin{array}{r}15.00 \\
6.33 \\
11.00 \\
9.67 \\
5.33 \\
8.00 \\
\end{array}$ & $\begin{array}{l}3.23 \mathrm{a} \\
2.90 \mathrm{a} \\
2.00 \mathrm{a} \\
1.00 \mathrm{a} \\
1.53 \mathrm{a} \\
3.30 \mathrm{a}\end{array}$ & $\begin{array}{l}3.67 \mathrm{a} \\
3.00 \mathrm{a} \\
3.00 \mathrm{a} \\
5.67 \mathrm{a} \\
2.83 \mathrm{a} \\
4.67 \mathrm{a} \\
\end{array}$ & $\begin{array}{l}3.40 \mathrm{a} \\
2.93 \mathrm{a} \\
2.40 \mathrm{a} \\
3.37 \mathrm{a} \\
2.07 \mathrm{a} \\
3.73 \mathrm{a}\end{array}$ \\
\hline C.V.\% & & 76.79 & 66.64 & 55.12 \\
\hline $\begin{array}{l}\text { Jassids: } \\
\text { NS-WE, 8\%w/v, } 2003 \\
\text { NS-WE, 8\%w/v, } 2004 \\
\text { NS-WE, 8\%w/v, } 2005 \\
\text { NSK-WE, 4\%w/v, 2005 } \\
\text { Valerate 20\%EC, (0.7L/ha) } \\
\text { Control (untreated) }\end{array}$ & $\begin{array}{l}0.00 \\
0.00 \\
0.00 \\
0.00 \\
0.00 \\
0.00\end{array}$ & $\begin{array}{r}23.53 \mathrm{~b} \\
18.00 \mathrm{~b} \\
24.43 \mathrm{~b} \\
19.47 \mathrm{~b} \\
7.43 \mathrm{~b} \\
92.00 \mathrm{a}\end{array}$ & $\begin{array}{l}21.33 \mathrm{~b} \\
22.67 \mathrm{~b} \\
18.30 \mathrm{bc} \\
18.10 \mathrm{bc} \\
5.57 \mathrm{c} \\
80.10 \mathrm{a} \\
\end{array}$ & $\begin{array}{l}22.47 \mathrm{~b} \\
20.33 \mathrm{bc} \\
21.40 \mathrm{bc} \\
18.80 \mathrm{bc} \\
6.50 \mathrm{c} \\
86.07 \mathrm{a} \\
\end{array}$ \\
\hline C.V.\% & & 31.58 & 26.62 & 26.70 \\
\hline $\begin{array}{l}\text { Leaf miners: } \\
\text { NS-WE, 8\%w/v, } 2003 \\
\text { NS-WE, 8\%w/v, } 2004 \\
\text { NS-WE, 8\%w/v, } 2005 \\
\text { NSK-WE, 4\%w/v, } 2005 \\
\text { Valerate 20\%EC, (0.7L/ha) } \\
\text { Control (untreated) }\end{array}$ & $\begin{array}{r}10.33 \\
8.67 \\
5.00 \\
6.00 \\
10.67 \\
11.00 \\
\end{array}$ & $\begin{array}{r}7.30 \mathrm{a} \\
7.03 \mathrm{a} \\
10.13 \mathrm{a} \\
9.67 \mathrm{a} \\
7.90 \mathrm{a} \\
11.57 \mathrm{a} \\
\end{array}$ & $\begin{array}{l}17.83 \mathrm{~b} \\
14.17 \mathrm{~b} \\
18.00 \mathrm{~b} \\
17.33 \mathrm{~b} \\
13.17 \mathrm{~b} \\
26.33 \mathrm{a}\end{array}$ & $\begin{array}{l}11.53 \mathrm{~b} \\
9.87 \mathrm{~b} \\
13.27 \mathrm{ab} \\
13.53 \mathrm{ab} \\
10.00 \mathrm{~b} \\
17.47 \mathrm{a} \\
\end{array}$ \\
\hline C.V.\% & & 27.82 & 18.39 & 19.19 \\
\hline $\begin{array}{l}\text { Predators: } \\
\text { NS-WE, 8\%w/v, } 2003 \\
\text { NS-WE, 8\%w/v, } 2004 \\
\text { NS-WE, 8\%w/v, } 2005 \\
\text { NSK-WE, 4\%w/v, } 2005 \\
\text { Valerate 20\%EC, (0.7L/ha) } \\
\text { Control (untreated) }\end{array}$ & $\begin{array}{l}1.67 \\
1.33 \\
0.67 \\
1.67 \\
2.67 \\
0.67 \\
\end{array}$ & $\begin{array}{l}2.89 \mathrm{ab} \\
2.78 \mathrm{abc} \\
2.22 \mathrm{bc} \\
3.11 \mathrm{ab} \\
1.00 \mathrm{c} \\
4.22 \mathrm{a} \\
\end{array}$ & $\begin{array}{l}3.55 \mathrm{ab} \\
1.11 \mathrm{~d} \\
2.67 \mathrm{bc} \\
2.78 \mathrm{abc} \\
1.56 \mathrm{~cd} \\
4.00 \mathrm{a} \\
\end{array}$ & $\begin{array}{l}3.22 \mathrm{a} \\
1.94 \mathrm{bc} \\
2.44 \mathrm{~b} \\
2.94 \mathrm{ab} \\
1.27 \mathrm{c} \\
4.11 \mathrm{a} \\
\end{array}$ \\
\hline C.V.\% & & 35.89 & 24.77 & 22.77 \\
\hline
\end{tabular}
in populations of most pests under field experiment, whereas, old seeds stored at $2-4$ years showed better efficacies than the fresher 1 year seeds under laboratory tests; Secondly, the declining of insecticidal activity in neem seeds used in the field was appeared at three years of storage, as opposite to five years under laboratory conditions. 
The reason for the above first point may be related to the fact that the fresh neem was acted both through bahavioural (e.g., repellent and antifeedant) and stomach toxicant effects in reducing field infestations, but the confined Trogoderma granarium larvae were deterred to some extent from feeding and acquiring the lethal dose from neem treated grains. It is reported that this pest can tolerate starvation for long periods without dying, as quoted by Ahmedani et al. (2007). However, the interpretation for the second contradicting point of field results was attributed to rapid degradation of neem bioactive compounds under open field circumstances as compared with the laboratory situation (Schmutterer, 1988).

All neem treatments sprayed on okra for pests control were significantly better than the commercial insecticide, Valerate 20\%EC, and the untreated controls in suppressing the populations of aphid. On the other hand, this pest reflected its highest zenith on the Valerate insecticide treatment without significant differences from the untreated control. Contrarily, the insecticide was performed better than the neem treatments in controlling jassid and leaf miners, and the results were significant particularly in case of the former pest. Table 3 also showed that the corticated and decorticated seeds were almost significantly identical in pests control, with little superiority of corticated seed extracts in combating aphids. Since decortication of neem seeds is difficult and time consuming, the application of corticated seeds seemed to be practically feasible. Moreover, the adoption of corticated seeds at the present applied dose $(8 \% \mathrm{w} / \mathrm{v})$ also conserved the use of neem kernels (cortex wt. $=54 \%$ of seed wt.), as compared with decorticated seeds (i.e., seed kernels) at the recommended dosage rate $(4 \% \mathrm{w} / \mathrm{v})$. However, neem treatments also reflected good results in conserving the prevailing predators, and sustained populations as high as that of the control in most cases. In this respect, Satti and Nasr (2006b) proved the safety of neem seed water extracts to the general predators on okra crop.

Consequently, as a result of the previously recorded pests control by neem treatments and Valerate insecticide, significant corresponding yield increases were obtained compared with the untreated control (Table 4). Although okra fruits showed scanty infestations by Earias species, significant control of this pest was recorded by all treatments. The corticated seeds of 1 year (2005) and 2 years (2004) old, produced the best significant total yields (18.51 and $19.54 \mathrm{~kg} /$ plot, respectively) and marketable yields (18.29 and 19.35), followed by the Valerate insecticide, decorticated seeds and lastly the oldest corticated seeds (2003). However, as mentioned before, the insecticide performed negatively in aphid control, but reported significantly the best control of other pests like jassid and leaf miners. So, why this treatment scored significantly better yield than some neem treatments can be attributed to some unclear reasons, but it is suggested that the grown okra cultivar (Pusa Sawani) may be more tolerant to aphid than to jassid infestation. Regarding decorticated and corticated seeds of the year 2005, it is obvious that there were no significant differences between the two treatments, although, the corticated ones were the best. This supported the idea of using neem seeds without removal of seed coats in preparing neem water extract. The presence of seed coat also seemed to facilitate grounding of kernels in a blender, preventing powder clogging due to the high oil content of neem kernels, and eventually increased the amount of the extract obtained, as reflected in the current results.

Table 4. Field evaluation of different treatments of neem seeds water extracts, prepared from products of three storage periods (2003 - 2005) on okra yields and fruit damage by Earias spp., during Jan. - March 2006.

\begin{tabular}{|l|l|l|l|}
\hline \multirow{2}{*}{ Treatments } & \multicolumn{3}{|c|}{ Average yields (kg/plot) of 6 pickings } \\
\cline { 2 - 4 } & Total & Infested & Marketable (sound) \\
\hline NS-WE, 8\%w/v, 2003 & $15.67 \mathrm{~b}$ & $0.11 \mathrm{bc}$ & $15.56 \mathrm{~b}$ \\
NS-WE, 8\%w/v, 2004 & $19.54 \mathrm{a}$ & $0.18 \mathrm{~b}$ & $19.35 \mathrm{a}$ \\
NS-WE, 8\%W/v, 2005 & $18.51 \mathrm{a}$ & $0.22 \mathrm{~b}$ & $18.29 \mathrm{a}$ \\
NSK-WE, 4\%W/v, 2005 & $17.31 \mathrm{ab}$ & $0.16 \mathrm{~b}$ & $17.16 \mathrm{ab}$ \\
Valerate 20\%EC, (0.7L/ha) & $18.22 \mathrm{a}$ & $0.02 \mathrm{c}$ & $18.20 \mathrm{a}$ \\
Control (untreated) & $13.22 \mathrm{c}$ & $0.47 \mathrm{a}$ & $12.76 \mathrm{c}$ \\
\hline C.V.\% & 7.47 & 37.22 & 7.67 \\
\hline
\end{tabular}

$>$ WE $=$ Water extract.

$>$ Means with the same letter (s), in each column, are not significantly different (at $p=0.05)$ according to Duncan's Multiples Range test. 


\section{CONCLUSIONS AND RECOMMENDATIONS}

- The results proved that water extract of neem seeds was effective as natural insecticides for combating storage and field pests, with comparable or even better performance than some conventional insecticides.

- Neem seeds of up to one year old seemed to have more repellant and antifeedant actions on insects than older seeds.

- Fruit berries stored in jute sacks for 2 to 4 years in shade under room conditions are the best in preparing neem extracts for store pests control, while seeds stored for 1 to 2 years are the best in field application.

- Corticated seeds applied at $8 \% \mathrm{w} / \mathrm{v}$ (80g neem seed powder/ 1L.water) exerted better insecticidal activities than decorticated seeds at $4 \% \mathrm{w} / \mathrm{v}$ ( $40 \mathrm{~g}$ neem seed kernel powder/ $1 \mathrm{~L}$.water). Application of corticated seeds is also more economical and easy to prepare, hence, it is strongly recommended to be used for pests' control at the indicated dosage rate, instead of decorticated ones.

\section{REFERENCES}

Abdel Bagi, A.O., Ahmed, A.A.M., Elhindi, M., and Ali, A.M. (2006). Impact of pesticides and other chemicals on the environment. Workshop on Post Conflict National Plan for Environmental Management in Sudan, 18 - 20 July 2006 Friendships Hall, Khartoum, Sudan.

Abdel Daffie, E.Y.A., Elhaj, E.A., and Bashir, N.H.H. (1987). Resistance in the cotton whitefly, Bemisia tabaci (Genn.), to insecticides recently introduced into Sudan Gezira. Tropical Pest Management, 33 (4): 283 $-286$.

Ahmed, N.S. (1997). Evaluation of neem (Azadirachta indica A. Juss) ) seed organic extracts on the control of okra pests. M.Sc. Thesis, Faculty of Agriculture, University of Khartoum, Sudan.

Ahmedani, M.S., Abdul Khaliq, M.T., Anwar, M. and Naz, S. (2007). Khapra beetle (Trogoderma granarium Everts): A serious threat to food security and safety. Pak. J. Agri. Sci., 44 (3): $481-493$.

Assad, Y.O.H., Bashir, N.H.H., and Eltoum, E.M.A. (2006). Evaluation of various insecticides on the cotton whitefly, Bemisia tabaci (Genn.); population control and development of resistance in Sudan Gerira. Resistance Pest Management Newsletter, 15 (2): 7 12.

Bashir, N.H.H. (1994). Studies on neem oil. Al Buhuth, 4 (1- B): $176-193$.

Dreyer, M. (1984). Effects of aqueous neem extracts and neem oil on the main pests of Cucurbita pepo in Togo.
Proc. $2^{\text {nd }}$ Int. Neem Conf., Rauischholzhausen, Germany, 1983, pp. 435 - 443.

Gorashi, N.E., Mohamed, S.A., Nasr, O.E., and Fadlelmula, A.M. (1994). The effect of neem seed kernels and leaves extracts on the development, feeding and mortality of the khapra beetle (Trogoderma granarium) larvae. Annual Scientific Report of ENRRI for the year 1993, NCR, Khartoum Sudan.

Ketkar, C.M. (1987). Use of tree-derived on-edible oils as surface protectants for stored legumes against Callosobruchus maculatus and C. chinensis. Proc. $3^{\text {rd }}$ Int. Neem Conf., Nairobi, Kenya, 1986, pp. 535 - 542.

Liedholm, B.O., and Amisi, J.L. (1986). Acetyl cholinesterase activity and organochlorine residues in the blood of DLCO-EA and plant protection staff in the Sudan. Crop Pest Management in the Sudan; Proceedings of a Symposium held in Khartoum, Feb. 1978, Ministry of Agriculture and Univ. of Khartoum, Khartoum University Press, Khartoum, pp. $409-415$.

Mohamed, E.S. (2002). Towards an integrated pest management (IPM) program on okra, Abelmoschus esculentus (L.) (Malvaceae). Ph.D. Thesis, Faculty of Agriculture, University of Khartoum.

Satti, A.A., Bashir, N.H.H., El Khidir, E., and Nasr, O.E. (2003). Effect of neem seed kernel and "handal" extracts on muskmelon pests complex. University of Khartoum Journal of Agricultural Sciences, 11 (1): 40 58.

Satti, A.A., and Nasr, O.E. (2006a). Effect of neem (Azadirachta indica A.Juss) seed powder and aqueous extract on the control of some major foliage insect pests of eggplant. Al Buhuth, 10 (1): $1-16$.

Satti, A.A., and Nasr, O.E. (2006b). Effect of neem (Azadirachta indica A.Juss) seed aqueous extract on okra insect pests and associated predators complex. Al Buhuth, 10 (2): 1 - 18.

Satti, A.A., Nasr, O.E., and Bashir, N.H.H. (2004). Technology of Natural pesticides: production and uses in Sudan. The Second National Pest Management Conference in the Sudan, 6 - 9 December 2004, Faculty of Agricultural Sciences, University of Gezira, Sudan.

Satti, A.A., Nasr, O.E. and Fadlelmula, A.M. (2002). Environmental value of the neem tree (Azadirachta indica A. Juss) and its role in socio-economic development. Seminar of the Industrial and Agricultural Uses of the Neem Tree and its Role in Development, 8 April 2002, Ministry of Agriculture and ForestryKhartoum/ Sudan.

Saxena, R.C. (1995). Pests of stored products. In: H. Schmutterer (ed.). The neem tree, Azadirachta indica A. Juss, and other meliaceous plants: source of unique natural products for integrated pest management, 
medicine, industry and other purposes. $\mathrm{VCH}$, Weinheim, pp. $418-432$.

Saxena, R.C., Jilani, G., and Abdul Karim, A. (1989). Effects of neem on stored grain insects. In: $M$. Jacobson (ed.), Focus on Phytochemical Pesticides, Vol. 1, The Neem Tree, Boca Raton; Arc Press, pp. 97 $-111$.

Schmutterer, H. (1988). Potential of azadirachtin containing pesticides for integrated control in developing and industrial countries. J. Insect Physiol. 34: 713 - 719.

Schmutterer, H. (1990). Properties and potential of natural pesticides from the neem tree, Azadirachta indica. Annual Review of Entomology, 35: 271 - 297.

Schmutterer, H. (1995). The neem tree, Azadirachta indica A. Juss, and other meliaceous plants: source of unique natural products for integrated pest management, medicine, industry and other purposes. $\mathrm{VCH}$,

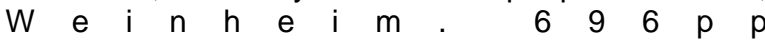

Siddig, S.A. (1987). An integrated pest management programme including neem treatments for combating potato pests in the Sudan. Proceeding $3^{\text {nd }}$ International Neem Conference, 1986, Nairobi, Kenya. pp. 449-459.

Siddig, S.A. (1991). Evaluation of neem seed and leaf water extracts and powders for the control of insect pests in the Sudan. Technical Bulletin No. 6, Shambat Research Station, Agricultural Research Corporation/ Sudan.

Whitehead, D.L., and Bowers, W.S. (1983). Natural products for innovative pest management (Current themes in tropical science) V. 2, 1st ed. Oxford (Oxford shire), New York, Pergamon Press. 550 pp.

Zein El Abdin, A. M., and Siragelnour, G. B. (1993). Behavioural and biological responses of Epilachna elaterii (Rossi) to neem. University of Khartoum Journal of Agricultural Sciences, 1 (1): 97-111. 